\title{
DIAKRONIKA
}

Vol. 17 No. 1 Th. 2017 p: 104 - 117

ISSN: 1411-1764 (Print) | 2620-9446 (Online)

http://diakronika.ppj.unp.ac.id

\section{Merancang Kegiatan Pembelajaran Sejarah Melalui Komik: Respon Terhadap Tantangan Kurikulum 2013}

\author{
Aisiah \\ Aisiah.unp@gmail.com \\ Universitas Negeri Padang
}

\begin{abstract}
Crucial issues, as well as the classic issues that have always been the subject of historical learning problems related to activities or learning processes that tend to be monotonous, boring and lack of innovation and creativity of the teachers in designing historical learning activities that can generate students interest and motivation in learning the history. The 2013 curriculum presents a special challenge for teachers to design student-centered learning activities using a scientific approach through problem-based learning models, project-based learning and discovery learning models. One solution that can be done by history teachers in answering the challenges of the 2013 curriculum is to design learning activities through historical comics. Historical teachers can apply problem-based learning models by utilizing historical comics that are already available on the market as well as on the internet. In addition, history teachers can also apply project-based learning models through activities of making comic history by learners in accordance with the historical learning material learned. The design of learning activities through comics is expected to create innovations in the form of historical comics as a result of the design and creativity of the students. The process of learning history through the making of comics is certainly based on a scientific approach and student-centered. History teachers are asked to direct, provide solutions and suggestions to improve the quality of learning activities and learning outcomes as well as the quality of historical comic produced by students.
\end{abstract}

Keywords: comic, learning history, problem based learning, project based learning

\begin{abstract}
Abstrak
Isu krusial, sekaligus isu klasik yang selalu menjadi pokok permasalahan pembelajaran sejarah berkaitan dengan kegiatan atau proses pembelajaran yang cenderung monoton, membosankan serta minimnya inovasi dan kreativitas guru dalam merancang aktivitas pembelajaran sejarah yang mampu membangkitkan minat dan motivasi belajar sejarah parapeserta didik. Kurikulum 2013 memberikan tantangan khusus bagi guru untuk merancang kegiatan pembelajaran yang berpusat pada peserta didik dengan menggunakan pendekatan saintifik melalui model pembelajaran berbasis masalah (problem based learning), pembelajaran berbasis proyek(project based learning) maupun model pembelajaran berbasis penemuan (discovery learning).Salah satu solusi yang dapat dilakukan oleh guru sejarah dalam menjawab tantangan kurikulum 2013 adalah dengan merancang kegiatan pembelajaran melalui komik sejarah.Guru sejarah dapat menerapkan model
\end{abstract}


Aisiah

Merancang Kegiatan Pembelajaran Sejarah Melalui Komik: Respon Terhadap Tantangan Kurikulum 2013

pembelajaran berbasis masalah dengan cara memanfaatkan komik sejarah yang telah tersedia di pasaran. Selain itu guru sejarah juga dapat menerapkan model pembelajaran berbasis proyek melalui kegiatan pembuatan komik sejarah oleh peserta didik sesuai dengan materi pelajaran yang dipelajari. Rancangan kegiatan pembelajaran melalui komik diharapkan dapat melahirkan inovasi berupa munculnya komik-komik sejarah hasil karya dan kreatifitas peserta didik. Proses pembelajaran sejarah melalui pembuatan komik tentu didasarkan pada pendekatan saintifik dan berpusat pada peserta didik. Guru sejarah dituntut mampu mengarahkan, memberi solusi dan saran untuk meningkatkan kualitas aktivitas pembelajaran dan hasil belajar maupun hasil karya komik sejarah peserta didik.

Kata Kunci: komik, pembelajaran sejarah, pembelajaran berbasis problem, pembelajaran berbasis proyek

This work is licensed under the Creative Commons Attribution-Share Alike 4.0 International License.

\section{Pendahuluan}

Isu krusial yang selalu menjadi sentral problematika pembelajaran sejarah dari dulu sampai hari ini melulu bergulat dengan persoalan minat dan motivasi belajar siswa. Di sisi lain yang jugamenjadi persoalan klasik adalah minimnya inovasi maupun kreativitas para guru sejarah dalam memperbaiki kualitas kegiatan pembelajaran sejarah. Berbagai upaya telah dilakukan untuk memperbaiki kualitas proses ataupun aktivitas pembelajaran sejarah baik oleh pemerintah melalui perubahan kurikulum dan segala konsekuensinya, maupun dilakukan oleh guru sendiri dengan cara menyesuaikan diri dengan tuntutan dan tantangan perubahan kurikulum.

Implementasi kurikulum 2013 berpedoman pada standar pendidikan nasional yang telah diatur dalam Peraturan Pemerintah Nomor 19 tahun 2005 tentang Standar Nasional Pendidikan. Paling tidak ada empat standar pendidikan nasional yang perlu menjadi perhatian guru sejarah dalam melaksanakan pembelajaran, yaknistandar kompetensi lulusan, standar isi, standar proses dan standar penilaian pembelajaran sejarah. Namun diantara empat standar tersebut, standar proses membutuhkan perhatian ekstra bagi guru-guru sejarah dalam menjawab tantangan pembelajaran kurikulum 2013.

Artikel ini mengkaji berbagai alternatif rancangan proses (kegiatan) pembelajaran sejarah yang mungkin bisa dilakukan oleh guru melalui media komik. Tujuannya untuk memberi ide pemikiran dan wawasan mengenai berbagai alternatif yang bisa dilakukan oleh guru sejarah dalam menjawab tantangan kurikulum 2013 dimana guru harus mampu merancang pembelajaran dengan pendekatan saintifik dan berpusat pada peserta didik melalui model, metode, sumber dan media belajar sesuai dengan karakteristik peserta didik dan karakteristik mata pelajaran. Pada mata 
pelajaran sejarah, ide desain pembelajaran sejarah yang sesuai dengan tuntutan kurikulum 2013 dapat dilakukan melalui komik sejarah dengan model pembelajaran problem based learning maupunproject based learning. Pembahasan dalam artikel ini diawali dengan gambaran umum mengeni kurikulum 2013, pengenalan tentang komik dan pemanfaatan komik dalam desain kegiatan pembelajaran sejarah.

Kurikulum 2013 menekankan pendekatan saintifik dan penggunaan model pembelajaran berbasis masalah (problem based learning), model pembelajaran berbasis proyek (project based learningmaupun model pembelajaran penemuan (discovery learning). Penekanan ini memberikan tantangan tersendiri bagi guru dalam merancang desain pembelajran. Konsekuensinya bagi pembelajaran sejarah adalah bagaimana mengemas pembelajaran sejarah yang selaras dengan tuntutan kurikulum 2013. Di sisi lain konsep pembelajaran sejarah yang dikemasoleh guru-guru sejarah hendaknya dapat memancing minat, memacu motivasi, kreativitas dan inovasi peserta didik maupun guru sejarah sendiri. Salah satu upaya yang dapat dilakukan oleh guru sejarah adalah dengan merancang proses pembelajaran melalui komik sejarah.Desain pembelajaran melalui komik sejarah potensial dapat mewujudkan pendekatan saintifik danpenerapan model-model pembelajaran yang disarankan dalam kurikulum 2013. Desain pembelajaran melalui komik sejarah tentu dapat memancing minat, motivasi, kreativitas dan inovasi para peserta didik maupun guru sejarah. Segala kemungkinan tersebut akan dikaji dalam penjelasan berikut.

Istilah komik dalam kamus besar bahasa Indonesia diartikan sebagai cerita bergambar dalam majalah, surat kabar atau cerita bergambar dalam bentuk buku yang umumnya mudah dicerna dan lucu. Intinya, komik adalah cerita bergambar yang menarik dan mudah dipahami oleh pembaca. Kaitan komik dengan pembelajaran sejarah adalah sama-sama berisi tentang cerita. Tiemensma (2009) menegaskan bahwa komik merupakan representasi bergambar dari suatu cerita. Komik berisi gabungan kata-kata dan gambar dengan cara yang unik dan menarik.Bagian terpenting dari sebuah komik mencakup tokoh (watak), dialog, gambar dan sudut info (Masariah Mispari dan Maktab Tentera Diraja, n.d.). Secara fundamental ada dua jenis komik yang umumnya sudah dikenal orang. Pertama komik strip (komik dalam bentuk kepingan/secarik komik), yaitu komik sederhana seperti yang ada dalam surat kabar atau majalah. Kedua, komik buku atau novel bergambar dengan ciri khas alur cerita yang lebih panjang. Akhir-akhir ini berkembang jenis komik baru, yakni komik web yang tersedia online di internet (Tiemensma, 2009). Komik web ini merupakan fasislitas layanan internet yang memungkinkan pengguna (user) dapat mengeksplorasi bahkan membuat 
komik sendiri. Istilah lain yang dilekatkan pada jenis komik web ini adalah "komik life", ada software khusus untuk menjalankannya.

Abad ke-21 menunjukkan tren perkembangan zaman yang digerakkan oleh kemajuan teknologi informasi dan komunikasi serta mempercepat proses globalisasi. Jaringan informasi dan komunikasi global begitu mudah diakses melalui media internet untuk berbagai keperluan, bahkan untuk dunia pendidikan. Saat ini proses pendidikan memasuki era digital dan kemunculan budaya visual yang membutuhkan kemampuan membaca tingkat tinggi. Penulisan komik mulai dikenal sejak abad ke-19. Tahun 1884 mulai muncul komik strip secara regular di Inggris, yakni komik Hero, Ally Sloper. Di Amerika, komik yang muncul pertama kali adalah komik tentang tokoh karakter the Yellow Kid tahun 1896. Semenjak tahun 1920-an penggunaan komik belum mendapat perhatian yang serius (Upson \& Hall, 2013). Namun pada perkembangan selanjutnya di Eropa (Belgia, Prancis, Italia, dan Jerman) komik strip lebih popular bahkan mulai dikemas dalam bentuk buku komik (dalam majalah anak-anak)dan telah diterbitkan oleh perusahan penerbit pada tahun 1930-an (Tiemensma, 2009).

Komik modern muncul tahun 1933, diprakarsai oleh perusahaan percetakan di Barat. Dekade 1940 diperkirakan 95\% anak usia 8-14 tahun, $65 \%$ remaja usia 15-18 tahun gemar membaca komik. Akademisi mulai menaruh perhatian melalui penelitian, penulisan dan perdebatan mengenai nilai edukasi dari komik (Upson \& Hall, 2013). Periode 1940-an s. d 1950-an dunia komik mengalami masa pasang surut dan ditandai dengan perdebatan panjang terutama dengan populernya komik berbau "horor" dan "criminal" yang berdampak tidak baik pada pembaca, khususnya anak-anak dan remaja. Kajian akademik sudah mulai dilakukan dalam memanfaatkan komik untuk kebutuhan pembelajaran. Penelitian mengenai kemungkinan pemanfaatan komik untuk kebutuhan pendidikan mulai dirintis oleh Will Eisner sejak 1950an. Universitas Pittsburg dan universitas New York bahkan mulai memikirkan dan memanfaatkan komik sebagai media belajar di sekolah-sekolah di Amerika. Namun demikian tetap ada muncul komik horor secara terselubung sampai akhir tahun 1960-an (Tiemensma, 2009).

Pada perkembangan berikutnyadunia komik mulai beralih kearah yang bernuansa intelektual dan mulai menjadi perhatian para sarjana pendidikan, khususnya di Eropa pada akhir tahun 1970-an dengan munculnya komik buku (novel) dalam bentuk grafik untuk pembaca dewasa (Tiemensma, 2009). Model pembelajaran dengan menggunakan komik telah teruji dan terbukti sejak lama. Eisner adalahsalah seorang pionir yang mengembangkan komik pembelajaran di sekolah-sekolah semenjak tahun 1950 s.d 1970. Eisner membagi komik pembelajaran ke dalam dua kategori, yakni jenis komik 
untuk pembelajaran teknik dan jenis komik untuk pembelajaran tingkah laku. Dengan demikian sejak 1980 komik telah mendapat perhatian yang positif dalam dunia akademis. Di Prancis dan Belgia (Eropa) komik dinilai penting sama seperti arsitektur, musik, film, lukisan dan sebagainya. Di Jepang publikasi komik didominasi oleh komik untuk semua kalangan usia. Di Amerika lebih berkembang komik superhero. Para psikolog,sosiolog maupun sejarawan mulai menyorot kekuatan komik yang mampu menunjukkan kekuatan komunikasi dan pemikiran yang komplek (Upson \& Hall, 2013). Di Amerika, Eropa, Jepang penerbitan komik lebih banyak mengarah pada bidang seni dan budaya.

Pada perkembangan terakhir eksplorasi komik mulai mengandalkan bentuk gambar digital melalui media internet, bahkan dunia film Hollywood seperti Spiderman, Superman, Batman dan lainnya diadopsi dari buku komik (Tiemensma, 2009). Eksplorasi terhadap potensi komik untuk keperluan pendidikan tentu semakin menginspirasi terutama dengan tersedianya fasilitas komik web dan segala fasilitas meupun kemudahan yang ditawarkan. Guru maupun peserta didik dapat berkolaborasi menciptakan komik untuk tujuan pendidikan. Dalam kaitannya dengan pendidikan dan pembelajaran sejarah, pemanfaatan maupun pembuatan komik oleh peserta didik sendiri ataupun oleh guru diharapkan dapat memancing minat dan motivasi belajar yang lebih baik. Harapannya kreativitas dan inovasi peserta didik maupun guru sejarah dalam membuat kmik sebagai media dan sumber belajar sejarah dapat dikembangkan, khususnya pembuatan komik, baik dalam bentuk komik strip, komik buku atau novel maupun komik web atau komik life.

Data Kemendikbud menunjukkan tahun 2015 sebanyak6.222 sekolah telah melaksanakan kurikulum 2013. Pemerintah menargetkan kurikulum 2013 sudah diterapkan di seluruh sekolah pada tahun 2018 (Tempo.Co, 2015). Hal ini menandakan bahwa tahun 2018 semua sekolah di Indonesia telah menerapkan kurikulum 2013. Kendala utama yang dihadapi dalam implementasi kurikulum 2013 berkenaandengan permasalahan proses pembelajaran. Landasan konseptual kurikulum 2013 antara lainlebih menekankan pada proses pembelajaran yang berfokus pada kompetensi, karakter dan keaktifan peserta didik (Mulyasa, 2014). Dalam kurikulum 2013 proses pembelajaranmenekankan pendekatan saintifik dan menggunakan model pembelajaran berbasis masalah, berbasis proyek dan diskoveri.

Penerapan pendekatan saintifik melalui model pembelajaran berbasis problem maupun model pembelajaran berbasis proyek diharapkan dapat melibatkan peserta didik agaraktif mengikuti berbagai bentukaktivitas proses pembelajaran dalam upaya meningkatkan penguasaan standar kompetensi dan pembentukan karakter mereka.Ini tentu menjadi tantangan tersendiri, 
khususnya bagi guru dan peserta didik dalam merealisasikan kegiatan atau proses pembelajaran yang bertumpu pada penerapan pendekatan saintifik dan menggunakan model pembelajaran yang dianjurkan dalam kurikulum 2013. Guru mau tidak mau harus mampu menyesuaikan diri dengan tantangan kurikulum 2013, di samping itu juga perlu didukung dengan media pembelajaran yang tepat. Dalam hal implementasi kurikulum 2013 untuk pembelajaran sejarah dapat dilakukan melalui model pembelajaran sejarah berbasis problem maupun model pembelajaran berbasis proyek melalui media komik dalam aktifitas pembelajaran.Kegiatan pembelajaran sejarah melalui media komik dapat dilakukan melalui dua cara. Pertama,pembelajaran sejarah dalam bentuk aktivitas mempelajari komik sejarah yang telah ada dan tersedia di pasaran maupun yang ada di internet melalui model pembelajaran berbasis masalah. Kedua, pembelajaran sejarah dalam bentuk aktivitas membuat komik sejarah melalui model pembelajaran berbasis proyek. Berikut penjelasan mengenai kedua hal tersebut.

Pelaksanaan proses pembelajaran sejarah dengan memanfaatkan media komik sejarah yang telah ada di pasaran atau yang telah tersedia di internet merupakan suatu ide kreatif yang bisa dilakukan oleh guru dan peserta didik. $\mathrm{Hal}$ ini diperkuat dengan temuan hasil penelitian yang menunjukkan bahwa peserta didik akan lebih tertarik pada pemanfaatkan media komik, tinimbang presentasi powerpoint, sebab komik mudah digunakan, atraktif, berdaya guna dan dapat memandu imajinasi sejarah daripada powerpoint dalam membahas informasi yang sama(Upson \& Hall, 2013; Webb, Balasubramanian, O'Broin, $\&$ Webb, 2012). Guru maupun peserta didik dapat membuat komik untuk menuangkan pengalaman pribadi mereka dalam bentuk cerita sejarah. Penggunaan komik dalam pembelajaran mampu menggugah rasa empati (Williams, 2008). Demikian juga dalam pembelajaran sejarah, komik menjadi media yang sangat efektif untuk menggugah empati sejarah (historical emparthy) peserta didik. Pemanfaatan komik dalam kegiatan pembelajaran sejarah dengan pendekatan saintifik sebagai ciri khas pelaksanaan kurikulum 2013 dapat dilakukan dengan memanfaatkan komik sejarah yang ada di pasaran atau yang telah tersedia di internet.Banyak komik biografi sejarah yang dihasilkan saat ini (Upson \& Hall, 2013). Guru dengan leluasadapat menerapakan model pembelajaran berbasis masalah(problem based learning)dengan pendekatan saintifik dan berpusat pada aktivitas peserta didik. Para peserta didik dapat belajar layaknya seorang sejarawan (ilmuwan) yang belajar atau bekerja dengan memanfaatkan media komik biografi sebagai media dan sebagai sumber belajar sejarah.

Contoh ide konkret yang ditawarkan dalam makalah ini adalah pembelajaran melalui komik biografi tokoh pahlawan nasional. Guru 
sejarahmenyajikan beberapa komik tentang biografi para tokoh pemimpin bangsa menurut periodesasi sejarah. Komik biografi tokoh pemimpin bangsa yang dapat dimanfaatkan, misalnya komik biografi Soekarno, Soeharto, Habibie, ataupun Susilo Bambang Yudhoyono. Komik-komik biografi yang telah ada dijadikan sebagai sumber sejarah dan sebagai sumber belajar sejarah. Siswa diminta mengamati, lalu diarahkan untuk mempertanyakan masalah seputar krisis kepemimpinan bangsa saat ini hingga muncul berbagai problem kepemimpinan yang akan dicari solusinya dengan menelusuri pengalaman kepemimpinan bangsa pada masa lalu.Selanjutnya siswa diminta mengumpulkan informasi dengan pendekatan historis melalui hasil bacaan dan analisis mereka terhadap komik-komik biografi sejarah dari masingmasing tokoh pemimpin bangsa.

Peserta didik belajar, mengamati, membaca, berdiskusi bahkan sambil berdebat dalam kelompok-kelompok kecil mengeluarkan argumen dan pemikiran kritis mereka. Para peserta didik melakukan aktivitas membaca, menggali dan menganalisis informasi dengan cara berdiskusi membahaskepribadian dan kepemimpinanpara pemimpin bangsa yang tergambar dalam komik. Selanjurnya peserta didik dapat membandingkan aspek-aspek kepemiminan bangsa dari dari masa ke masa sembari mengaitkannya dengan kondisi krisis kepemimpinan yang terjadi saat ini. Peserta didik dituntut mampu menunjukkan bukti keunggulan kepemimpinan Soekarno, Soeharto, Habibie dan Susilo Bambang Yudhoyono untuk selanjutnya dikaji dan dianalisis sampai dihasilkan mereka menemukan kriteria pemimpin ideal yang dibutuhkan bangsa di masa yang akan datang yang disarikan daripengalaman perjalanan historis para pemimpin bangsa terdahulu. Peserta didik kemudian diminta mengevaluasi dan mengkomunikasikan hasil diskusi kelompok kecil dalam bentuk cerita sejarahdan dibimbing oleh guru.Cerita sejarah mengenai perilaku dan kepemimpinan tokoh dalam komik memberikan peluang untuk meniru perilaku ideal (Upson \& Hall, 2013). Kemampuan siswa menceritakan atau menerangkan cerita sejarah yang ada dalam komik memungkinkan munculnya nilai-nilai kesejarahan dalam dalam diri peserta didik saat aktivitas pembelajaran berlangsung. Peserta didik menganalisis perilaku tokoh (pemimpin-pemimpin bangsa) yang ada dalam cerita komik dan menginternalisasi nilai-nilai kehidupan yang positif dari kepemimpinan para pemimpin bangsa.

Pembelajaran sejarah melalui komik yang telah ada di pasaran maupun yang telah tersedia di internet seperti komik biografi tokoh sejarah sebagaimana yang ditawarkan di atas tentu tidak semudah membicarakan alur kerjanya. Tugas utama guru sebagai fasilitator pembelajaran sejarah adalah menyediakan media komik biografi sejarah yang relevan dengan tujuan atau 
tuntutan kompetensi dasar dan indikator capaian belajar sejarah yang ditargetkan. Kreativitas guru sangat dituntut dan ini menjadi salah satu faktor yang turut menentukan kesuksesan implementasi kurikulum 2013 (Mulyasa, 2014). Guru berkewajiban menyediakan media pembelajaran yang akan dimanfaatkan oleh peserta didik untuk menunjang aktivitas belajar mereka. Jika aktivitas pembelajaran melaui media belajar menggunakan komik yang telah ada di pasaran, maka guru dapat membeli komik sejarah yang relevan di toko-toko buku maupun secara online. Secara historis sebenarnya para profesor sejarah telah memanfaatkan komik yang telah ada di masa lalu sebagai dokumen sejarah yang dapat membuka cakrawala terhadap persoalan dan fokus perhatian zaman sekarang (Upson \& Hall, 2013). Namun jika guru mengalami kendala, misalkomik sejarah (biografi) belum banyak beredar di pasaran, maka guru mesti memikirkan solusinya. Di sinilah letak kreativitas dan kompetensi guru dalam menjalankan tugasnya sebagai fasilitator pembelajaran. Upaya lain yang bisa dilakukan adalah dengan membuat sendiri media komik yang dibutuhkan dan dapat disesuaikan dengan tuntutan capaian pembelajaran atau sebaliknya memikirkan ide kreatif lain dengan melibatkan peserta didik dalam membuat media komik untuk mengegakkan prinsip belajar yang berpusat pada aktivitas dan keaktifan peserta didik.

Pembelajaran sejarah melalui komik potensial dapat melibatkan peserta didik yang tidak menaruh minat pada pembelajaran membaca (Upson \& Hall, 2013). Guru yang kreatif tentu akan mengarahkan peserta didikdengan kecenderungan minat baca rendah pada aktivitas pembelajaran yang mengandalkan kecakapan tulis-menulis, khususnya kecakapan membuat gambar komik. Keberadaan atau ketersediaan komik yang cocok untuk media pembelajaran saat ini masih terbatas (Tiemensma, 2009). Pembuatan komik sejarah sebagai media belajar dan pembuatan komik sebagai sebuah proses belajar sejarah dapat dilakukan oleh peserta didikDalam pembelajaran sejarah kondisi ini potensial untuk merangsang kreativitas guru maupun siswa dalam mengembangkan komik yang dapat dijadikan sebagai media belajar, sekaligus sebagai sumber belajar (Upson \& Hall, 2013), khususnya sebgai sumber belajar sejarah. Namun hal penting yang mesti menjadi perhatian guru adalah kehati-hatian dalam menentukan dan menyusun konten pembelajaran sejarah yang mendukung pencapaian tujuan pendidikan (pembelajaran) sejarah.

Contoh konkret yang ditawarkan dalam makalah ini misalnya adalah membuat komik tentang "peristiwa penting seputar proklamasi."Model pembelajaran yang digunakan untuk menjawab tantangan kurikulum 2013 adalah pembelajaran berbasis pada proyek (project based learning). Pembuatan komik dilakukan oleh peserta didik secara berkelompok dan dikumpulkan pada waktu ujian akhir semester dan menjadi bagian dari 
penilaian potofolio para peserta didik. Proses pembelajaran berlangsung melalui pembuatan proyek (tugas) berupa komik sejarah tidak mesti selalu dilaksanakan dalam kelas. Pembagian kelompok dilakukan oleh guru dengan memperhatikan perbedaan (kecakapan dan minat) pribadi peserta didik (Mulyasa, 2014). Jenis komik yang dibuat diarahkan pada jenis komik buku (novel sejarah). Peserta didik belajar dan bekerja dalam kelompok dengan pembagian tugas sesuai dengan kapasitas mereka. Peserta didik yang trampil menggambar diberi tugas menggambar komik. Peserta didik yang trampil menelusur sumber-suber sejarah diberi kesempatan dan tugas untuk mencari dan mempelajari konten cerita sejarah mengenai peristiwa seputar proklamasi. Sementara peserta didik yang cekatan menulis skenario diminta menulis alur cerita sejarah mengenai peristiwa penting seputar proklamasi.

Penerapan pendekatan saintifik dalam pembelajaran berbasis proyek membuat komik tentang peristiwa penting seputar proklamasi diawali dengan pengarahan awal dari guru. Pada tahap awal guru bisa saja memperlihatkan foto Soekarno sedang membacakan teks proklamasi. Peserta didik kemudian diminta mengamati dan mempertanyakan foto yang mereka lihat dan amati. Baru kemudian guru mengorganisirpara peserta didik untuk mencari informasi dan menyusunnya dalam bentuk cerita singkat dan membuat gambar komik sebagai tahapan penting dalam proses pembuatan komik. Kerja kelompok merupakan bagian penting dalam melaksanakan tugas pembelajaran berbasis proyek. Anggota kelompok mesti saling berbagi dan bekerjasama merumuskan desain komik dan menganalisis tugas proyek (Barge, 2010).Tahap selanjutnya dalam pembelajaran berbasis proyek adalah membuat komik tentang peristiwa penting seputar proklamasi dan mempresentasikan hasil kerja proyek yang dihasilkan dari masing-masing kelompok. Tugas guru selanjutnya adalah memberikan penilaian portofolio peserta didik. Kreativitas guru tidak hanya sampai pada tahap menilai dan menentukan hasil kerja proyek yang paling bagus nilainya. Guru bisa mengarahkan peserta didik lebih lanjut. Hasil karya peserta didik berupa komik tentang peristiwa penting seputar proklamasi bisa saja diikutkan dalam ajang perlombaan karya ilmiah. Ini tentu akan memantik motivasi peserta didik untuk belajar dan menghasilkan karya ilmiah yang lebih baik melalui pendekatan saintifik. Pembuatan komik sejarah mustahil bisa dilakukan oleh peserta didik tanpa mengumpulkan bukti atau sumber sejarah dan menginterpretasikannya dalam bentuk cerita sejarah menurut sudut pandang (penafsiran) peserta didik berdasarkan proses ilmiah yang mereka lakukan.

Ciri khas penggunaan media komik dalam pembelajaran sejarah ditunjukkan oleh fakta-fakta sejarah yang kemudian diterjemahkan menjadi gambar dan dialog karakterter/tokoh. Artinya materi pembelajaran sejarah 
yang disampaikan dalam bentuk komik tentu dikemas dalam bentuk cerita bergambar, lengkap dengan dialog para tokoh atau pelaku sejarah.Secara umum ada tiga alasan utama mengapa komik memiliki manfaat penting sebagai media pembelajaran. Pertama, peserta didik biasanya memiliki ketertarikan atau hobi dengan genre komik.Kedua, komik relatif murah dan mudah didapatkan. Ketiga, pilihan kata (kosakata) dalam komik tidak sulit sehingga mudah dibaca dan dipahami. Dalam komik, kata-kata, gambar, layout dan cerita sebagai elemen atau bagian dalam komik tidak didominasi oleh bacaan. Peserta didik tentu akan lebih menikmati sistem bacaan yang berbentuk gabungan dari gambar dan teks. Komik menawarkan kesempatan pada peserta didik untuk mencermati dengan penuh ketelitian bagaimana saling keterkaitan antara gambar dan kata-kata mampu membentuk suatu rangkaian narasi yang kuat (Williams, 2008; Wright \& Sherman, 1999). Pasangan gambar dan kata-kata (teks) merupakan cara yang mudah untuk membantu peserta didik dalam mengembangkan kemampuan visual yang lebih kuat.

Komik memiliki kemampuan menghadirkan materi pelajaran yang kompleks dan dapat membantu siswa dalam bidang studi seperti studi sain dan studi sosial.Peserta didik dapat mempelajari bagian cerita melalui aktivitas membaca komik. Komik dapat digunakan untuk pembelajaran konsep. Komik dalam bentuk novel misalnya memiliki alur certia yang jelas. Ada awal, ada proses dan ada akhir cerita. Ada karakter atau tokoh utama yang ditonjolkan dalam konflik dan klimaks cerita (Tiemensma, 2009). Pembelajaran sejarah melalui komik dalam bentuk novel sejarah memiliki potensi yang luar biasa dalammengasah kemampuan peserta didik menganalisis konteks sejarah dan kemampuan untuk menemukan makna di balik cerita peristiwa sejarah yang dibaca. Selain itu aktivitas membaca komik dalam bentuk novel sejarah juga dapat menumbuhkan kepedulian, kepekaan atau rasa empati peserta didik terhadap tokoh sejarah. Membaca kombinasi teks dan gambar (komik) memberikan tantangan kepada peserta didik karena memerlukan upaya lebih ketimbang membaca buku teks biasa. Peserta didik dilatih memahami dan menafsirkan kaitan antara gambar dan teks. Kondisi ini dapat menarik minat peserta didik karena mereka ditantang untuk terlibat dalam suasana cerita sejarah dalam komik. Jika para peserta didik telah memiliki minat yang kuat pada pembelajaran sejarah dengan membaca komik sejarah tentu mereka akan termotivasi untuk belajar sejarah lebih giat sambil menyalurkan hobi membaca dan berimajinasi dalam membuat komik.

Kreatifitas peserta didik terus ditantang ketika mereka dituntut untuk mampu berimajinasi membayangkan pengalaman kehidupan masa lampau dengan segenap peristiwa yang telah terjadi dan menuangkannya dalam 
bentuk karya berupa komik. Semakin banyak karya komik yang dihasilkan peserta didik tentu dengan sendirinya akan melahirkan inovasi-inovasi baru berupa ragam media pembelajaran sejarah dalam bentuk komik.

Komik dapat dimanfaatkan untuk memberikan kesempatan dan stimulus kepada para peserta didik untuk bereksplorasi dalam proses pembuatan komik. Rancangan teks dalam komik mengarahkan peserta didik untuk menyelidiki isu sosial yang krusial. Komik potensial melahirkan rasa empati peserta didik dengan tokoh sejarah yang ditampilkan dalam komik. Misal komik tentang agresi militer Belanda di Indonesia, atau peristiwa G. $30 \mathrm{~S}$. Kegiatan membaca atau membuat komik tentang peristiwa ini tentu tidak mungkin tidak akan melahirkan rasa empati peserta didik yang membaca atau membuatnya. Rasa empati terhadap tokoh sejarah muncul ketika peserta didik membayangkan dirinya berada pada posisi yang sama dengan tokoh sejarah yang diceritakan dalam komik, terutama ketika tokoh sejarah tersebut menghadapi berbagai konflik yang terjadi dalam peristiwa sejarah. Peserta didik mengamati pergulatan tokoh sejarah dan membawakan dalam dirinya secara personal. Kondisi ini memacu peserta didik untuk bereaksi terhadap peristiwa sejarah yang dipelajari. Empati merupakan satu hal yang paling penting dihasilkan dari jenis materi sejarah berupa konfllik atau perang. Latihan membuat komik berpotensi terhadap kemungkinan menggunakan komik di kelas sejarah atas potensi komik sebagai sumber utama dalam belajar sejarah. Serial komik buku akan berdaya guna lebih baik dalam pembelajaran sejarah dan menjadi stategi yang efektif untuk memperkaya pengalaman peserta didik dalam pembelajaran sejarah (Decker \& Castro, 2012).

Penelitian (Aiken, 2010) menunjukkan bahwa "buku komik adalah sejarah." Komik menjadi sumber utama budaya populer. Komik telah muncul dengan konteks yang lebih spesifik, ada yang mencerminkan situasi politik, prasangka dan kepedulian terhadap momen sejarah tertentu. Komik juga dapat membentuk pandangan generasi muda. Komik superhero merupakan sebuah tawaran yang sangat istimewa dan berharga sebagai sebuah pendekatan untuk melibatkan para peserta didik dalam latar sejarah. Tampilan komik dapat berisi poster, propaganda pemerintah, film, dan cuplikan berita penting. Media komik dapat memberikan kesempatan untuk memperkenalkan isu-isu ras dan isu etnis, serta untuk membahas konsepkonsep tertentu dalam pembelajaran sejarah.

Lyga (2006) menegaskan bahwa dalam pembelajaran komik dibutuhkan kemampuan memahami sekuen (urutan) peristiwa, menafsirkan gestur tokoh, membedakan alur cerita dan membuat simpulan. Mengusung buku komik ke dalam kelas tampaknya merupakan suatu langkah disarankan bagi guru 
Aisiah

Merancang Kegiatan Pembelajaran Sejarah Melalui Komik: Respon Terhadap Tantangan Kurikulum 2013

sejarah hari ini. Guru bisa menarapkan hari komik, atau minta bantuan dan kepedulian pemerintah untuk menyediakan komik gratis di sekolah. Komik superhero merupaka cara efektif untuk mengeksplorasi kecintaan pada sejarah. Untuk banyak alasan, superhero berkesan bagi peserta didik. Keberadaan komik superhero memungkinkan guru dan peserta didik untuk memeriksa konsep gender, ras, patriotisme, dan perubahan sejarah melalui kacamata yang benar-banar baru (Aiken, 2010).

Komik pernah diejek sebagai teks rendahan yang tidak bernilai dalam pembelajaran di kelas selama beberapa waktu. Namun kemudian komik baru mulai dapat diterima dan digunakan sebagai sumber pembelajaran. Komik bisa saja menjadi bahan pembelajaran yang sangat efektif (Upson \& Hall, 2013). Komik memiliki fungsi pendidikan yang luar biasa dan potensial untuk digarap oleh para akademisi dan pendidik. Komik cocok digunakan dalam pembelajaran dan mencapai tujuan-tujuan pembelajaran (Upson \& Hall, 2013). Komik adalah media hiburan yang sangat akrab dengan anak-anak dan remaja sebagai generasi muda dan diakui keberadaannya. Tetapi kemampuan komik untuk mendidik bahkan menghibur di kalangan akademisi, belum dipahami secara universal (Upson \& Hall, 2013). Ini tentu menjadi tantangan tersendiri bagi guru dan peserta didik untuk menciptakan komik yang memiliki nilai akademis sekaligus menghibur dan dapat membangun karakter generasi muda.

\section{Simpulan}

Sudah menjadi rahasia umum dan alasan klasik bahwa pembelajaran sejarah belum mendapatkan posisi tawar yang membanggakan. Mata pelajaran dan pembelajaran sejarah masih terus berjuang agar memperoleh tempat istimewa dalam diri peserta didik dan guru sekalipun. Minat dan motivasi belajar sejarah peserta didik perlu ditingkatkan terus dengan berbagai cara dan berbagai media belajar. Guru sejarah pelu membagun kepercayaan diri sebagai guru sejarah yang profesional. Guru sejarah harus mampu menunjukkan pendekatan profesional pada mata pelajaran sejarah dengan mempromosikan pelajaran sejarah sebagai sebagai mata pelajaran wajib di sekolah. Di samping itu guru mesti berpikir positif dan menunjukkan kepedulian pada mata pelajaran sejarah.

Kurikulum 2013 memberikan tuntutan dan tantangan kepada guru sejarah agar dapat mengemas proses pembelajaran sejarah yang saintifik serta mampu memantik minat dan motivasi belajar peserta didik agar gengsinya dapat ditingkatkan. Salah satunya melalui pembelajaran komik. Dalam imlementasi kurikulum 2013 pembelajaran sejarah melalui media komik 
memberikan peluang dan tantangan tersendiri bagi guru dan peserta didik. Peluang dan tantangan tersebut dapat ditindaklanjuti dengan memanfaatkan komik yang sudah ada di pasaranatau yang ada tersedia di internet sebagai media belajar sejarah atau dengan menciptakan sendiri komik sejarah yang relevan dengan kompetensi dasar pembelajaran sejarah baik oleh guru maupun oleh peserta didik. Komik sejarah sebagai sebuah media pembelajaran tentu memiliki keunggulan dan kelemahan. Tidak ada gading yang tidak retak. Tidak ada satu media yang sempurna, semua mempunyai kelebihan dan kelemahan, selanjutnya yang dituntut adalah adalah bagaimana kreativitas guru dalam menyiasatinya.

\section{Daftar Rujukan}

Aiken, K. G. (2010). Superhero history: Using comic books to teach US history. OAH Magazine of History, 24(2), 41-47.

Barge, S. (2010). Principles of problem and project based learning: The Aalborg PBL model. Massachusetts: Aalborg University.

Decker, A. C., \& Castro, M. (2012). Teaching history with comic books: A case study of violence, war, and the graphic novel. The History Teacher, 45(2), 169-187.

Lyga, A. A. W. (2006). Graphic Novels for (Really) Young Readers: Owly, Buzzboy, Pinky and Stinky. Who Are These Guys? And Why Aren't They Ever on The Shelf?. School Library Journal, 52(3), 56.

Masariah Mispari dan Maktab Tentera Diraja. (n.d.). Pembelajaran melalui komik sejarah. Malaysia.

Mulyasa. (2014). Pengembangan dan implementasi kurikulum 2013: perubahan dan pengembangan kurikulum 2013 merupakan persoalan penting dan genting. Bandung: PT Remaja Rosdakarya.

Tempo.Co. (2015). Kurikulum 2013 berlaku di seluruh sekolah 2018. Retrieved from https://nasional.tempo.co/read/638143/kurikulum-2013berlaku-di-seluruh-sekolah-2018

Tiemensma, L. (2009). Visual literacy: to comics or not to comics? Promoting literacy using comics. 75Th IFLA General Conference and Council, 1-10. Milan: World Library and information congress.

Upson, M., \& Hall, C. M. (2013). Comic book guy in the classroom: The educational power and potential of graphic storytelling in library instruction. Kansas Library Association College and University Libraries Section Proceedings, 3(1), 28-38.

Webb, E. N., Balasubramanian, G., O’Broin, U., \& Webb, J. M. (2012). WHAM! POW!: comics as user assistance. Journal of Usability Studies, 7(3), 105-117.

Williams, R. M.-C. (2008). Image, text, and story: Comics and graphic novels 
Aisiah

Merancang Kegiatan Pembelajaran Sejarah Melalui Komik: Respon Terhadap Tantangan Kurikulum 2013

in the classroom. Art Education, 61(6), 13-19.

Wright, G., \& Sherman, R. (1999). Let's create a comic strip. Reading Improvement, 36(2), 66. 